\title{
HUBUNGAN DIVIDEN INISIASI DAN INFORMASI ASIMETRI: PENDEKATAN HAZARD RATE
}

\author{
Hadri Kusuma \\ Fakultas Ekonomi \\ Universitas Islam Indonesia Yogyakarta
}

\begin{abstract}
This research examines the dynamics of dividend policy applying the hazard model. The study focuses on the dividend initiation for a sample of firms went public on the Jakarta Stock Exchange between 1990 and 1997. These dividend initiations are investigated in the contect of pecking order theory. The results of the tests indicate that the hazard rate of a dividend initiation is negatively related to both level of asymmetric information and growth, but positively related to the level of agency costs. The results are consitent with the theory of pecking order but do not provide a support for a signaling theory.
\end{abstract}

\section{PENDAHULUAN}

Keputusan dividen mungkin merupakan salah satu keputusan yang paling kontroversi diantara keputusan jangka panjang pembiayaan keuangan perusahaan. Miller dan Modigliani (1961) meletakan dasar-dasar teoritis dalam mengkaji kebijakan dividen perusahaan. Menurut mereka, pada pasar yang sempurna kebijakan dividen tidak memiliki pengaruh terhadap kemakmuran pemegang saham bila kebijakan investasi perusahaan tidak mengalami perubahan. Dengan kata lain, semakin tinggi rasio pembayaran dividen mengakibatkan semakin rendah laba yang ditahan dan capital gains, demikian juga sebaliknya, sehingga investor wealth tidak terpengaruh. Berlawanan dengan Modiglinai dan Miller, hasil penelitian Lintner (1956) menunjukan bahwa perusahaan-perusahaan secara umum mengikuti proses yang adaptif dalam kebijaksaanan dividennya. Pihak perusahaan cenderung tidak menurunkan jumlah dividen yang dibayarkan. Bahkan mereka cenderung masih mendistribusikan dividen seperti pada periode-periode sebelumnya walaupun perusahaan tersebut mengalami penurunan laba bersih. Di samping itu pihak perusahaan cenderung meningkatkan dividen bila yakin terjadi peningkatan yang permanen atas laba bersihnya. Hasil-hasil penelitian sebelumnya mendukung kebijakan dividen stabil seperti temuan Lintner tersebut (lihat misalnya Lasfer, 1996; Denter dan Warther, 1998; dan Aivazian et al, 2001).

Dalam literatur manejemen keuangan, sejumlah teori diusulkan untuk menjelaskan fenomena dividen tersebut. Model agensi bisa digunakan untuk menjelaskan dividend puzzle tersebut. Menurut teori agensi, jika 
laba (profit) tidak dibagikan kepada pemegang saham, laba tersebut mungkin akan dialokasikan pada proyek-proyek yang kurang menguntungkan (unprofitable projects) sehingga menguntungkan manajemen perusahaan atau mungkin digunakan untuk keperluan personal. Dengan kata lain pemegang saham lebih menyukai dividen dari pada laba yang ditahan (retained earnings). Teori signaling juga merupakan penjelas fenomena dividen. Sejumlah literature empiris menunjukan bahwa harga saham merespon pengumuman perubahaan dividen (unexpected dividend changes). Secara umum hasil penelitian terbut menunjukan rata-rata harga saham akan bereaksi positif (negatif) atas pengumuman kenaikan (penurunan) dividen. Bhattacharya (1979) dan Miller dan Rock (1985) misalnya mengembangkan model-model yang memiliki muatan informasi mengenai prospek laba perusahaan masa mendatang. Hasil penelitian mereka menunjukan dividen yang tinggi berasosiasi dengan dengan laba sekarang dan masa datang yang tinggi pula. Ini berarti terdapat hubungan yang positif antara harga saham dengan arah perubahan dividen. Model mereka juga memprediksikan bahwa besarnya respon harga saham akan merupakan fungsi poisitif dari besarnya perubahan dividen. Hasil penelitian dan model ini didukung juga oleh hasil penelitian yang dilakukan oleh Aharony dan Swany (1980) dan Asquith dan Mullins (1983). Akan tetapi bukti yang diberikan oleh DeAngelo et al. (1996) dan Benartzi et al. 1997 menunjukan bahwa perubahan dividen sekarang tidak bisa digunakan untuk memprediksi laba (earnings) masa mendatang. Karenanya, bukti yang berkaitan teori signaling masih inconclusive.

Penelitian ini dimaksudkan untuk menguji fenomena perubahan dividen dalam kontek informasi asimetri dengan model yang dikembangkan oleh Deshmukh (2004). Penjelasan fenomena dividen didasarkan pada teory pecking order yang diusulkan oleh Myers (1984) dan Myers dan Majluf (1984). Teori ini memiliki implikasi terhadap kebijaksanan dividen yang sering diabaikan dalam literatur kebijakan dividen. Menurut Myers dan Majluf, bila terjadi asimetri informasi antara perusahaan dengan para investor luar, pihak perusahaan mungkin akan melakukan underinvestment dengan menggunakan slack (memupuk cadangan keuntungan sebesarbesarnya). Myers dan Majluf juga mengatakan bahwa suatu perusahaan dapat memperbanyak slack melalui melalui retensi (retention) sehingga dividen menjadi lebih rendah. Oleh karena itu kebijakan dividen dapat digunakan untuk mengendalikan masalah underinvestment sebagai akibat asimetri informasi.

Penelitian ini memfokuskan pengujian efek informasi asimetri terhadap perubahan dividen. Pendekatan ini memberikan bukti langsung dalam mengkaji hubungan antara asimetri informasi dengan perubahan dividen. Pendekatan ini berbeda dengan penelitian-penelitian sebelumnya 
yang menggunakan reaksi harga saham terhadap pengumuman perubahan dividen dalam menjelaskan fenomena dividen dan karenanya tidak memberikan bukti langsung mengenai hubungan antara perubahan dividen dengan faktor-faktor penjelasnya. Sejalan dengan prosedur pengujian yang dilakukan oleh Deshmukh (2003), penelitian ini berbeda dengan penelitianpenelitian sebelumnya dalam tiga (3) hal.

Pertama, penelitian ini menguji dividen inisiasi perusahaan-perusahaan yang masuk bursa efek Jakarta selama periode 1990-1997 dan perkembangannya tahun 1990-2000. Dividen inisiasi menggambarkan suatu perubahan dividen dari sebesar nol menjadi jumlah yang positif. Menurut Asquith dan Mullins (1983), dividen inisiasi kurang diharapkan dibandingkan dengan kenaikan atau penurunan dividend. Dividen inisiasi juga merefleksikan suatu pergeseran yang signifikan (significant shift) dalam kebijakan dividen perusahaan. Oleh karena itu, dividen inisiasi bisa memberikan penjelasan kerangka teori yang mendasari implikasi teoritisnya (theoretical implication). Disamping itu, teori seharusnya bisa digunakan untuk memprediksi bila status perusahaan berubah dari belum membayar (non-paying status) menjadi pembayar dividen. Sampel penelitian yang berupa perusahaan yang baru memasuki bursa efek menggambarkan kelompok perusahaan yang sedang mengalami pertumbuhan, rendah aliran kas dan cenderung membutuhkan dana dari luar dalam jumlah besar. Disisi lain, kelompok perusahaan ini juga menghadapi masalah informasi asimetri yang lebih tinggi karena masih relatif muda. Oleh karena itu, karakteristik sampel penelitian bisa memberikan latar belakang (background) yang ideal dalam menguji efek asimetri informasi terhadap perubahan dividen. Pemilihan sampel dengan fokus pada perusahaanperusahaan yang baru memasuki bursa efek juga mengikuti persyaratan sampel yang homogen (Deshmukh, 2003).

Kedua, sampel dalam penelitian ini memasukan perusahaan yang belum membayar dividen sama sekali dan perusahaan yang telah membayar dividen inisiasi. Penelitian sebelumnya umumnya tidak memasukan sampel kelompok perusahaan pertama. Dikeluarkannya kelompok perusahaan yang belum bisa membayar dividen secara optimal akan berakibat sampel yang dipilih menjadi bias sehingga parameter yang diestimasi juga bias dan tidak konsisten. Oleh karena itu generalisasi hasil penelitian sebelumnya mengenai kebijakan dividen menjadi kurang akurat. Memasukan kelompok perusahaan yang belum membayar dividen dalam penelitian bisa membantu dalam mengatasi potensi masalah dalam pemilihan sampel dan bisa berfungsi sebagai kelompok sampel pengontrol bagi kelompok sampel dividen inisiasi (Deshmukh, 2003). Dalam penelitian ini parameter model empiris diestimasi dengan teknik maximum likelihood. 
Terakhir, penelitian ini menggunakan data kejadian historis (event history data) dan mengestimasi model kemungkinan (hazard or duration model). Dibandingkan dengan penggunaan data panel, metode event history memberikan hasil yang lebih baik. Metode event history banyak digunakan dalam literature science, engineering dan economics. Aplikasi model ini dalam literature keuangan sangat jarang digunakan. Penggunaan data event history dan entimasi model hazard memungkinkan untuk menguji secara dinamis hubungan asimetri informasi dengan perubahan dividen (Deshmukh, 2003). Sub bagian metode penelitian mendiskusikan secara rinci argumen dan rasional penggunaan model hazard dan pemodelan dividen inisiasi.

\section{FORMULASI HIPOTESA}

\section{Pecking Order Theory}

Dalam literatur keuangan disebutkan bahwa informasi asimetri terjadi dalam kegiatan manajemen perusahaan. Pihak manajemen seringkali mempunyai informasi yang lebih dalam mengenai perusahaan yang tak bisa didapatkan oleh investor ekternal. Perbedaan kemampuan mengakses informasi antara manajemen dan investor sering disebut asymmetry information (asimetri informasi). Salah satu teori yang digunakan untuk menjelaskan masalah informasi asimetri adalah teori pecking order: suatu teori yang menjelaskan urutan sumber pendanaan atau menentukan hirarki sumber dana yang paling disukai seperti dikemukakan oleh Myers dan Majluf (1984) dan Myers (1984). Teori ini juga menjelaskan alasan perusahaan-perusahaan yang profitable meminjam dalam jumlah yang sedikit. Perusahaan tidak bersedia meminjam dalam jumlah besar bukan dimaksudkan untuk mengejar target debt ratio yang rendah, tetapi karena menginginkan external financing yang rendah. Sementara, perusahaanperusahaan yang kurang profitable akan cenderung mempunyai hutang yang lebih besar karena dana internal tidak cukup dan atau hutang merupakan sumber eksternal yang paling disukai.

Lebih lanjut menurut teori pecking order theory, sumber pembiayaan dari internal lebih disukai karena memungkinkan perusahaan untuk tidak perlu membuka diri dari sorotan external investors, sementara dana eksternal dalam bentuk hutang lebih disukai karena flotation costs hutang lebih murah dibandingkan dengan emisi saham baru dan karena manajemen perusahaan khawatir bahwa emisi saham baru akan ditafsirkan sebagai informasi buruk (bad news) bagi external investors. Apapun alasan preferensi sumber pembiayaan yang digunakan oleh pihak perusahan, pemilihan tersebut memungkinkan terjadinya informasi asimetri antara pihak manajemen (pihak dalam) dengan pihak investor (pihak luar). 
Kebijakan pembayaran dividen (dividen policy) merupakan keputusan untuk menentukan besarnya bagian laba (earning) yang akan dibagikan pada pemegang saham dan bagian yang akan ditahan di perusahaan. Alokasi laba untuk kedua tujuan tersebut merupakan keputusan yang bertolak belakang. Bila perusahaan sedang mengalami pertumbuhan, distribusi laba kepada pemegang saham yang tinggi mengharuskan perusahaan mencari sumber pembiayaan dari luar. Begitu juga sebaliknya, bila jumlah dividen yang dibagikan rendah pihak perusahaan bisa dianggap memupuk laba untuk mencapai kepentingan pribadi manajemen.

Myers dan Majluf (1984) berpendapat bila terjadi asimetri informasi antara pihak manajemen dengan pihak investor eksternal, pihak perusahaan mungkin akan melakukan kebijakan underinvestment. Kebijakan ini diambil karena adanya kekhawatiran persepsi negatif berupa penurunan nilai bila perusahaan mengeluarkan surat berharga baru (new issues of capital) sebagai sumber pembiayaan. Kerangka teori Myers dan Majluf ini mengimplikasikan bahwa semakin tinggi tingkat informasi asimetri, semakin tinggi kemungkinan perusahaan melakukan underinvestment. Myers dan Majluf menyarankan, pihak perusahaan dapat mengurangi underinvestment dengan meningkatkan jumlah slack melalui retensi (retention) sehingga dividen menjadi lebih rendah. Dengan demikian, semakin tinggi tingkat asimetri informasi maka semakin rendah dividen dalam mengendalikan underinvestment. Dengan kata lain teori pecking order memprediksikan semakin tinggi tingkat informasi asimetri, semakin rendah kemungkinan (hazard rate) dividen inisiasi. Alternatifnya, semakin tinggi tingkat informasi asimetri, semakin lama jangka waktu dilakukannya dividen inisiasi oleh perusahaan.

Walaupun dengan menggunakan metodelogi yang berbeda, keberadaan teori pecking order di Indonesia pernah diuji sebelumnya oleh Sartono (2000). Sartono mengkaji alasan perusahaan meningkatkan dana baru: apakah akan cenderung mempertahankan target capital struktur atau cenderung menggunakan hirarki pendanaan. Sartono menyimpulkan perusahaan-perusahaan go publik di Indonesia cenderung mengikuti hirarki pendanaan atau pecking order theory. Studi lain dilakukan oleh Pangeran (2000) juga menujunkan bahwa pemilihan penawaran sekuritas di Indonesia konsiten dengan filosofi teori pecking order.

\section{Signaling Theory}

Teori lain dan paling sering digunakan untuk menjelaskan kebijakan dividen perusahaan adalah teori signaling. Dalam kontek ini, pembayaran dividen merupakan sinyal bagi investor luar mengenai prospek perusahaan masa datang. Modigliani dan Miller (1961) berpendapat bahwa suatu kenaikan dividen di atas normal merupakan suatu sinyal kepada in- 
vestor bahwa manajemen perusahaan memepunyai ekspektasi yang baik di masa datang. Sebaliknya, suatu penurunan dividen dianggap sebagai suatu sinyal "kesulitan" perusahaan masa datang.

Bukti empiris yang diberikan oleh Bhattachary (1979, Aharony dan Swany (1980), dan Asquith dan Mullins (1983) menunjukan dividen yang tinggi berasosiasi dengan dengan laba sekarang dan masa datang yang tinggi pula. Ini berarti bahwa dividen mempunyai hubungan positif dengan reaksi harga saham. Menurut Aquith dan Mullins (1983), adanya pengaruh positif dari kebijakan pembayaran dividen disebabkan adanya mekanisme yang dapat mengkomunikasikan informasi manajemen mengenai kinerja perusahaan saat ini dan masa datang. Bahkan Miller dan Rock (1982) menyatakan bahwa adanya informasi asimetri antara investor dan manajemen karena perubahan pembayaran dividen akan berdampak pada reaksi harga saham di pasar. Miller dan Rock (1982) juga mengemukakan bahwa dividen yang tidak diantisipasi memberikan sinyal perubahan earnings dan cash flows perusahaan masa datang. Perusahaan membayar dividen untuk menyampaikan informasi kepada investor dengan biaya yang lebih murah dan kredibel.

Ross (1977) menyatakan bahwa dua asumsi yang mendasari dividen sebagai sinyal. Pertama manajemen perusahaan merasa enggan untuk merubah kebijakan dividennya. Karena itu, apabila terjadi kenaikan pembagian dividen yang dilakukan oleh manajemen, investor luar akan menganggap sebagai suatu sinyal bahwa perusahaan mempunyai prospek dimasa datang. Kedua, kedalaman informasi yang dimiliki investor dan manajemen berbeda. Manajemen biasanya memiliki informasi yang lebih mendalam tentang kondisi perusahaan yang sebenarnya. Fenomena ini bisa terjadi karena adanya information asymmetry diantara manajer dan investor.

Sejalan dengan pemikiran Ross (1977) tersebut, Miller dan Rock (1985) mengembangkan suatu model mengenai hubungan antara informasi asimetri dengan tingkat laba sekarang (current earning) dan tingkat investasi perusahaan (level of investment). Menurut Miller dan Rock (1985), karena earnings diasumsikan berkorelasi dari waktu ke waktu, investor luar bisa memprediksikan earnings masa datang bila laba sekarang diketahui. Karena tingkat investasi sulit dicermati (unobservable), pihak perusahaan mempunyai insentif membayar dividen yang lebih besar untuk memberikan sinyal earnings yang lebih tinggi dengan mengurangi investasi. Dalam keadaan ekuilibrium, suatu perusahaan dengan current earnings yang lebih tinggi membayar dividen yang cukup tinggi untuk membedakannya dengan perusahaan yang mendapatkan current earnings yang lebih rendah. Kondisi ini juga menunjukan tingkat pembayaran dividen juga lebih tinggi dengan keberadaan informasi asimetri bila dibandingkan dengan keadaan 
informasi penuh. Argumen di atas mengindikasikan bahwa kelompok perusahaan dengan tingkat asimetri informasi yang tinggi akan membayar dividen yang lebih tingi pula untuk memberikan sinyal tingkat earnings yang sama seperti perusahaan dengan tingkat asimetri yang lebih rendah. Cateris paribus, teori signaling memprediksikan semakin tinggi tingkat informasi asimetri, semakin tinggi juga kemungkinan (hazard rate) dividen inisiasi. Alternatifnya, semakin tinggi tingkat informasi asimetri, semakin rendah waktu yang diperlukan sampai dengan pembayaran dividen inisiasi.

\section{METODE PENELITIAN}

\section{Sampel}

Sampel dalam penelitian ini dalah seluruh perusahaan yang melakukan penawaran perdana (initial public offering) di Bursa Efek Jakarta tahun 1990 sampai 1997. Perusahaan-perusahaan tersebut kemudian diamati selama periode 1990-2000 untuk menentukan apakah membayar dividen inisasi atau tidak. Perusahaan yang menjadi sampel juga memiliki data keuangan yang lengkap dan bukan dari kelompok industri keuangan. Dari 234 perusahaan yang melakukan penawaran perdana selama 19901997, hanya 80 perusahaan yang memenuhi kriteria di atas. Selama periode pengamatan 1990-2000, 54 perusahaan membayarkan dividen inisiasi. Bila suatu perusahaan membayar dividen inisisasi pada tahun tertentu, perusahaan tersebut pada tahun berikutnya dikeluarkan dari sampel, tatapi perusahaan tidak membayar selama periode pengamatan tetap dimasukan sebagai sampel. Jumlah observasi yang masuk dalam kategori ini sebanyak 54 observasi dari 26 perusahaan. Dengan demikian data yang diolah sebanyak 102 observasi.

\section{VARIABEL PENELITIAN}

\section{Hazard Rate}

Penelitian ini membahas pengaruh informasi asimetri terhadap kebijakan dividen tanpa mengesampingkan potensi faktor-faktor lain juga yang berperan dalam menentukan kebijakan dividen. Untuk memperbaiki spesifikasi empiris ini, penulis mengidentifikasi beberapa faktor dari model empiris sebelumnya dan berfungsi sebagai variabel pengontrol (control variable) dalam kebijakan dividen. Keberadaan informasi asimetri dan variabel lain mengindikasikan bahwa kebijakan dividen yang optimal merupakan fungsi dari atribut-atribut khusus perusahaan (firm-specific attributes). Keputusan untuk tidak membayar dividen oleh perusahaan didasarkan atas suatu kenyataan bahwa tingkat dividen optimal perusahaan adalah sebesar nol. Argumen ini mensyiratkan bahwa kelompok perusahaan yang belum 
membayar dividen ini menganggap optimal bila mereka belum membagikan dividen dan seharusnya tidak diabaikan dalam menganalisa kebijakan dividen yang dilakukan oleh perusahaan.

Konsep dividen inisiasi dalam penelitian ini dapat diuraikan sebagai berikut. Setiap periode, tingkat dividen optimal suatu perusahaan ditentukan oleh firm-specific attributes. Perusahaan membagikan dividen inisiasi jika tingkat dividen optimalnya adalah positif atau keadaan sebaliknya menahan untuk tidak membayar dividen. Alternatifnya, dividen inisiasi suatu perusahaan dapat dipandang sebagai suatu pergeseran (shift) dari tingkat pembayaran dividen yang optimal sebesar nol menjadi nilai yang positif. Pergeseran ini dapat disebabkan oleh firm-specific attributes. Kemungkinan (likelihood) bahwa suatu perusahaan membagikan dividen inisiasi akan bergantung pada kemungkinan bahwa tingkat dividen optimal berasumsi positif. Oleh karena itu, probabilitas dividen inisiasi merupakan fungsi masalah informasi asimetri dan berbagai firm-specific attributes.

Kemungkinan pembayaran dividen inisiasi digambarkan oleh hazard rate (probability), $h$ (t). Hazard rate adalah tingkat (rate) di mana suatu peristiwa terjadi pada waktu $t$ dan belum terjadi sebelumnya. Dalam penelitian ini, hazard rate adalah tingkat (rate) di mana perusahaan bergeser dari belum membayar dividen kemudian membayar pertama kalinya (initiation). Hazard rate (atau probability) berhubungan terbalik dengan lama atau waktu hingga perusahaan membayar dividen inisiasi kepada pemegang saham. Oleh sebab itu, semakin tinggi hazard rate, maka semakin rendah waktu yang dibutuhkan sampai pembayaran dividen permulaan, begitu sebaliknya.

\section{Informasi Asimetri}

Pengaruh informasi asimetri terhadap hazard rate yang diprediksikan teori signaling dan pecking order berlawanan dan merupakan teori dasar yang digunakan untuk menjelaskan fenomena dividen dalam penelitian ini. Tingkat informasi asimetri antara pihak perusahaan dengan investor luar diukur dengan skala perusahaan (firm size). Penelitian-penelitian sebelumnya banyak yang mengggunakan ukuran perusahaan sebagai proxy informasi asimetri, diantaranya Atiase (1985), Collin et al. (1985), Bhushan (1990), dan Deshmukh (2003). Sebagai misal, Bhushan berpendapat bahwa jumlah analis yang mengikuti suatu perusahaan seharusnya fungsi positif ukuran perusahaan: semakin banyak analis yang mencermati semakin kecil tingkat informasi asimetri. Bhushan menemukan bukti yang konsisten dengan hipotesanya tersebut.

Dalam penelitian ini ukuran perusahaan (MVSIZE) merupakan logarithm market value of equity. Semakin besar ukuran perusahaan, semakin rendah informasi asimetri antara pihak perusahaan dengan investor 
luar. Oleh karena itu, teori pecking order memprediksikan: semakin besar ukuran perusahaan maka semakin besar hazard rate dividen inisiasi. Sebaliknya, menurut teori signaling semakin besar skala perusahaan maka akan semakin kecil hazard rate dividen inisiasi. Oleh karena itu, arah koefisien MVSIZE akan membedakan teori yang akan didukung. Disamping itu, penelitian ini juga mengidentifikasi pengaruh variabel lain sebagai faktor pengendali (control variable) untuk mmperbaiki spesifikas penelitian ini. Variabel control yang digunakan adalah agency costs, cash flow, dan growth. Variabel-variabel tersebut sebelumnya secara signifikan juga berhubungan dengan kebijakan dividen.

\section{Biaya Agen (Agency Cost)}

Menurut Agus Sartono (2001) berbagai konflik kepentingan dalam perusahaan banyak disebabkan karena masalah keagenan. Hubungan keagenan merupakan suatu kontrak di mana satu atau lebih orang (prinsipal) memerintah orang lain (agen) untuk melakukan suatu jasa atas nama prinsipal serta memberikan wewenang kepada agen untuk membuat keputusan yang terbaik bagi prinsipal. Rozeff (1982) dan Easterbrook (1984) berpendapat bahwa dividen dapat digunakan sebagai mekanisme untuk mengurangi mekanisme biaya keagenan bagi kepemilikan luar (external equity). Menurut Easterbrook, biaya agen dapat terjadi dari pemonitoran manajer dan aversi risiko manajerial (managerial risk aversion). Permasalahan yang berhubungan dengan pemonitoran dan risiko aversi akan berkurang jika para manajer sering berkomunikasi dengan pihak external capital market untuk mendapatkan sumber pendanaan. Logikanya, manajer yang sering diawasi pihak pasar modal kemungkinan besar akan bertindak mengikuti kepentingan semua pihak (claimants) untuk memperleh harga terbaik ketika mengeluarkan surat berharga. Komunikasi dengan pihak pasar modal kemungkinan bisa terjadi bila perusahaan membayar dividen yang lebih tinggi dan menghadapi kebutuhan dana untuk investasi. Rozeff juga memperkirakan peranan pemonitoran dividen dan melihat pembayaran dividen sebagai alat pengikat yang digunakan untuk mengurangi biaya agen. Penelitian ini menggunakan jumlah pemegang saham suatu perusahaan yang dilogaritmakan sebagai proxy biaya keagenan (LOGSHHOL). Semakin besar jumlah pemegang saham, semakin besar penyebaran kepemilikan sehingga semakin besar biaya keagenan (Rozeff, 1982). Oleh karena itu hazard rate dividen inisiasi seharusnya berkorelasi positif dengan jumlah saham (LOGSHHOL).

\section{Cash Flow}

Menurut teori signaling, bila segala sesuatunya konstan perusahaan dengan current earnings yang tinggi diprediksikan akan membayar 
dividen yang tinggi pula. Sama halnya dengan teori pecking order memprediksikan semakin tingggi aliran kas perusahaan, semakin rendah slack yang diperlukan sehingga pembayaran dividen akan semakin tinggi. Logika ini sejalan dengan Benartzi et al. (1997) yang menemukan hubungan positif antara dividen dengan contemporaneous earnings. Oleh karena itu, waktu yang diperlukan hingga membayar dividen berhubungan terbalik dengan aliran kas. Akan tetapi, hazard rate dividen inisiasi seharusnya fungsi positif aliran kas (CFTOB). Dalam penelitian ini, rasio aliran kas dari operasi terhadap nilai buku akiva digunakan sebagai proxy aliran kas seperti yang dilakukan oleh Opler dan Titman (1993).

\section{Pertumbuhan Perusahaan (Growth)}

Besarnya laba yang akan dibagikan sebagai dividen terkait dengan besarnya dana yang dibutuhkan perusahaan dan kebijakan manajer perusahaan mengenai sumber dana yang akan digunakan. Salah satu alternatif pemenuhan kebutuan dana berasal dari intern dan penahanan laba yang di peroleh perusahaan. Perusahaan yang sedang mengalami pertumbuhan membutuhkan dana yang lebih besar, sehingga kebijakan dividen yang diambil perusahaan mungkin akan terpengaruh. Smits dan Watts (1992) menyatakan bahwa pertumbuhan perusahaan akan mempengaruhi sejumlah kebijakan dividen yang dibuat perusahaan seperti kebijakan pendanaan, dividen dan kompensasi.

Menurut Myers dan Majluf (1984), kemungkinan melakukan underinvestment akan semakin tinggi bila perusahaan memiliki kesempatan tumbuh. Kemungkinan underinvestment bisa dikurangi dengan meningkatkan jumlah slack yang tersedia. Argumen Myers dan Majluf tersebut berimplikasi tingkat dividen seharusnya berkorelasi terbalik dengan pertumbuhan perusahaan. Penelitian ini menggunakan rasio nilai pasar aktiva terhadap nilai buku (MTOB) sebagai proxy pertumbuhan perusahaan seperti yang dilakukan diantaranya oleh Smith dan Watts (1992), Opler dan Titman (1993) dan D'Mello dan Ferris (2000). Oleh karena itu, semakin tinggi nilai MTOB, semakin rendah hazard rate inisiasi. Dengan kata lain, waktu yang diperlukan hingga membayar dividen inisiasi berbanding lurus dengan nilai MTOB.

MODEL ANALISIS

Hubungan hazard rate dengan dividen inisiasi dapat dinyatakan dengan formula berikut ini:

$h_{t}=\beta_{0}+\beta^{\prime} X$

(1)

dimana : $h_{t}=$ Hazard rate suatu perusahaan pada waktu $t$

$X=$ vektor variabel penjelas 
Vektor variabel bebas $\mathrm{X}$ terdiri dari variabel informasi asimetri dan beberapa variabel kontrol. Model pada persamaan tersebut merupakan model event history yang menghasikan hazard rate atau kemungkinan dividen inisiasi suatu perusahaan. Parameter slope $(\beta)$ menggambarkan dampak marginal variabel bebas terhadap kemungkinan (hazard rate) perusahaan yang akan membayar dividen inisiasi. Persamaan di atas juga tidak berisi faktor-faktor yang belum teridentifikasi (random disturbance). Ini berarti model tersebut tidak deterministic sebagai akibat hubungan random yang terjadi antara tingkat kemungkinan tidak bisa diobservasi (unobservable hazard rate) dan waktu t hingga perusahaan membagikan dividen inisiasi (Allison, 1984).

Konsep utama menganalisa dengan event history adalah kisaran resiko (risk set). Kisaran resiko dalam penelitian ini adalah kumpulan semua perusahaan yang menghadapi resiko dividen inisiasi. Dengan kata lain, kisaran resiko berisi semua perusahaan yang belum membayar dividen (non-dividend-paying firms). Bila suatu perusahaan membayar dividen inisisasi pada tahun tertentu, perusahaan tersebut bukan merupakan bagian kisaran resiko pada tahun berikutnya dan dikeluarkan dari sampel. Dengan demikian, kisaran resiko periode selanjutnya akan berkurang dengan jumlah perusahaan membayar dividen inisiasi tahun sebelumnya. Hal inilah yang membedakan kisaran data event history dengan data panel. Berbeda dengan kumpulan data panel, tidak semua perusahaan menyumbangkan jumlah observasi yang sama dalam kumpulan data event history. Suatu perusahaan akan tetap di dalam sampel selama perushaan tersebut belum membayar dividen inisisasi. Ketika perusahaan membayar dividen permulaan, perusahaan tersebut dikeluarkan dari sampel dan tidak lagi berhadapan dengan resiko kejadian inisiasi. Proses mengobservasi suatu perusahaan hingga pembayaran dividen inisiasinya memugkinan untuk mendeteksi perkembangan atau evolusi suatu perusahaan dari waktu ke waktu dan menghasilkan pengujian yang lebih kuat mengenai faktor-faktor mempengaruhi inisiasi. Dalam kontek ini, kisaran data event history memberikan informasi lebih kaya dibandingkan dengan data panel, yang hanya memberikan informasi faktor-faktor pada waktu terjadinya saja (Allison, 1984).

Teknik OLS (ordinary least squares) tidak akurat digunakan dalam kontek model hazard karena dua kharakteristik yang melekat pada data event history: censoring dan time-varying explanatory variables. Sebagai contoh, penelitian ini memilih periode pengujian selama 10 tahun. Periode 10 tahun mungkin tidak cukup panjang untuk mengobservasi setiap sampel yang memulai pembayaran dividen inisiasi. Jika jumlah observasi yang disensor merupakan bagian yang signifikan dari sampel keseluruhan, mengabaikan bagian sampel tersebut bisa menciptakan hasil yang bias. 
Dengan demikian, OLS tidak akurat. Kedua, OLS tidak menyediakan media yang akurat untuk menjelaskan time-varying explanatory variables (Allison, 1984). Karenanya, dengan adanya censoring dan time-varying explanatory variables, penggunaan metode maximum likelihood akan akurat dalam mengestimasi persamaan 1.

\section{STATISTIK DESKRIPTIF}

Tabel 1 menunjukkan statistik deskriptif variabel penelitian selama periode pengamatan 1990-1997 dengan sampel berjumlah 80 perusahaan atau observasi 102. Rata-rata lamanya waktu yang diperlukan untuk membayar dividen inisiasi semenjak perusahaan masuk bursa efek adalah 415 hari atau 17 bulan dengan penyimpangan baku 264 hari. Sementara itu, nilai logaritma ukuran perusahaan yang menggambarkan informasi asimetri 1,497623 dengan nilai tengah sebesar 1,60206. Rata-rata logaritma jumlah pemegang saham $-1,54986$ nilai tengah-1,45593 dan penyimpangan baku saham 0,701008 .

Tabel 1: Statistik Deskriptif

\begin{tabular}{|l|c|c|r|r|r|r|}
\hline \multirow{2}{*}{ PARAMETER } & \multicolumn{2}{|c|}{$\begin{array}{c}\text { LAMA DIVIDEN } \\
\text { INISIASI }\end{array}$} & \multirow{2}{*}{ MVESIZE } & \multirow{2}{*}{ LOGSHOOL } & \multirow{2}{*}{ CFTOB } & \multirow{2}{*}{ MTOB } \\
\cline { 2 - 4 } & HARI & \multicolumn{1}{|c|}{ BULAN } & & & & \\
\hline RATA-RATA & 415 & 17 & 1,497623 & $-1,54986$ & 5,255142 & 1,337647 \\
\hline STD DIVIASI & 264 & 14 & 0,881936 & 0,701008 & 9,043221 & 0,304828 \\
\hline MEDIAN & 350 & 12 & 1,60206 & $-1,45593$ & 2,020618 & 1,266853 \\
\hline
\end{tabular}

Mean ratio nilai buku pasar dibagi nilai buku aktiva (MTOB) seluruh perusahaan sebesar 1,337647, dengan nilai tengah sebesar 1,266853 dan penyimpangan baku sebesar 0,304828. MTOB mencerminkan kesempatan pertumbuhan suatu perusahaan secara keseluruhan. Sementara itu, rata-rata aliran kas operasi terhadap nilai buku aktiva (CFTOB), yang mencerminkan nilai aliran kas suatu perusahaan, sebesar 5,255142 dengan nilai tengah sebesar 9,043221 dan penyimpangan baku sebesar 2,020618.

\section{ANALISIS DATA DAN PEMBAHASAN}

Bagian ini menyajikan analisa data berdasarkan pengamatan sejumlah variabel yang dipakai dalam teknik regresi berganda dengan metode hazard rate atau probability. Sebagaimana yang telah diuraikan pada sebelumnya, bahwa penelitian ini melibatkan variabel tergantung kemungkinan pembayaran dividen permulaan (hazard rate) dan empat variabel 
bebas: informasi asimetri (MVESIZE), biaya agen (LOGSHOOL), aliran kas (CFTOB), pertumbuhan atau kesempatan investasi (MTOB). Untuk mengecek validitas (robust) hasil pengujian, persamaan 1 diestimasi dengan metode parametrik dan semiparametrik yang meliputi model discrete-time dan continous-time.

\section{Metode Parametrik Discrete-Time}

Bagian ini menguraikan teknik dan hasil pengujian hipotesa dengan metode discreate time. Metode discreate time menekankan pada kemungkinan (probablity) dividen inisiasi selama periode tertentu. Misalkan, $P(t)$ menggambarkan hazard rate waktu tertentu (descrete time). Dalam penelitian ini, $\mathrm{P}(\mathrm{t})$ merupakan kemungkinan non-dividend paying firms akan memulai pembagian dividendn pada tahun tertentu. Setelah variabel tergantung pada persamaan 1 ditransformasikan ke dalam bentuk logit, persamaan tersebut akan menggambarkan discrete time sebagai berikut:

$\log \left(\frac{P(t)}{1-P(t)}\right)=\beta 0+\beta^{\prime} X$

Dari persamaan 2 di atas, besarnya variabel tergantung bisa bervariasi antara minus hingga positif tak terbatas. Koefisien variabel bebas $(X)$ menggambarkan perubahan pada log odds dividen inisiasi akibat setiap perubahan satu (1) unit variable bebas. Spesifikasi pada persamaan 2 di atas menunjukan bahwa hazard rate, $\mathrm{p}(\mathrm{t})$, bervariasi hanya dengan variable bebas dan tidak dengan waktu. Dengan kata lain, hazard rate diasumsikan tidak tergantung dengan waktu.

Setiap tahun selama periode pengamatan 1997-2000, kisaran resiko dibentuk dan berisi hanya satu observasi untuk setiap perusahaan. Observasi kemudian dikumpulkan (pooled) untuk membentuk satu sampel. Periode observasi dimulai bila perusahaan melakukan IPO (initial public offering) dan berakhir tahun 2000 atau bila membagikan dividen inisiasi, mana yang terjadi terlebih dahulu. Oleh karena itu, perusahaan yang memulai atau membayar dividen pada tahun pertama setelah IPO tidak memiliki kisaran resiko pada tahun berikutnya dan menyumbangkan hanya satu observasi dalam sampel. Di lain pihak, perusahaan yang tidak membagikan dividen selama periode pengamatan (tahun ke 6) akan disensor dan menyumbangkan hingga 6 observasi dalam sampel. Sampel keseluruhan (pooled sample) kemudian berisi censoring dan keberadaan timevarying explanatory variables. Untuk itu, setiap tahun akan membentuk variable dummy yang bernilai satu bila membagikan dividen inisiasi pada tahun yang bersangkutan. Estimasi persamaan 2 kemudian menjadi estimasi dengan metode logit dengan tekhnik maximum likelihood. 
Hasil pengujian yang disajikan dalam tabel 2 menunjukan bahwa hazard rate berhubungan secara positif dengan ukuran perusahaan (MVESIZE) dan kesempatan tumbuh (MTOB), tetapi berasosiasi negatif dengan biaya keagenan (LOGSCHOOL). Tanda positif pada koefisien ukuran perusahaan mengindikasikan bahwa perusahaan besar yang kurang memiliki informasi asimetri (less information asymmetry) cenderung membayarkan dividen awal. Tanda positif pada varaibel MVESIZE juga konsisten dengan teori pecking order, tapi tidak sejalan dengan teori signaling. Tidak signifikannya koefisien variabel aliran kas (CFTOB) menunjukan bahwa keputusan untuk membayar dividen awal tidak dipengaruhi oleh jumlah kas yang tersedia. Secara keseluruhan metode discrete-time mendukung teori pecking order. Hasil penelitian ini juga konsisten dengan penelitian Deskhmukh (2003) tetapi berlwanan hasil pengujian yang dilakukan Litner (1961), Fama (1956), Bachattara (1979), dan Miller dan Rock (1985). Selanjutnya hasil penelitian ini diuji validitasnya dengan metode continous-time parametric dan semiparametric continous time.

Tabel 2: Hasil Pengujian Persamaan 2

\begin{tabular}{|c|c|c|c|c|}
\hline & Coefficient & Std. Error & z-Statistic & Prob. \\
\hline $\mathrm{C}$ & -2.013558 & 0.506874 & -3.972501 & $0.0001^{*}$ \\
\hline MVESIZE & 0.099568 & 0.046394 & 2.146138 & $0.0319^{*}$ \\
\hline LOGSHOOL & -0.267484 & 0.056660 & -4.720896 & $0.0000^{*}$ \\
\hline CFTOB & -0.016892 & 0.011615 & -1.454279 & 0.1459 \\
\hline MTOB & 0.812528 & 0.263227 & 3.086795 & $0.0020^{*}$ \\
\hline Log likelihood & -93.10470 & & & \\
\hline Left censored obs & 48 & \multicolumn{2}{|c|}{ Right censored obs } & 0 \\
\hline Uncensored obs & 54 & \multicolumn{2}{|l|}{ Total obs } & 102 \\
\hline
\end{tabular}

* signifikan pada $\square=5 \%$

\section{Metode Continous-Time Parametric}

Literature keuangan mengenai kebijakan dividen tidak menyediakan prediksi yang dapat menghubungan dividen inisiasi dan waktu. Ini berarti hazard rate dividen inisiasi diasumsikan tidak bervariasi dengan waktu. Distribusi eksponensial waktu hingga membayarkan dividen berarti hazard rate yang independent terhadap waktu. Dengan kata lain, model ekponensial menghasilkan kemungkinan (hazard) yang konstan. Model regresi tersebut dirumuskan sebagai berikut:

$\log \left(\mathbf{h}_{\mathrm{t}}\right)=\boldsymbol{\beta O}_{\mathrm{O}}+\boldsymbol{\beta}^{\prime} \mathbf{X}_{n}^{t}$

Model pada persamaan 3 di atas merupakan model regresi eksponensial dari persamaan 1 . Karena $h_{\mathrm{t}}$, hazard rate waktu t, tidak mungkin bernilai nol $(0)$, adalah tidak tepat mengekspresikan $h_{t}$ sebagai fungsi liner 
variabel bebas. Akan tetapi, transformasi logaritma menghasilkan $\log \left(\mathrm{h}_{\mathrm{t}}\right)$ yang dapat mengasumsikan semua nilai dan bebas bervariasi dengan variabel bebas. Varaibel tergantung menggambarkan hazard rate dividen inisiasi. Koefisien-koefisien dari persamaan 3 tersebut menunjukan pengaruh variabel bebas terhadap hazard rate dividen inisiasi. Koefisien bertanda negatif berarti semakin rendah hazard rate dan semakin lama hingga dividen inisiasi.

Hasil pada table 3 menunjukan hazard rate dividen inisiasi berasosiasi positif dengan ukuran perusahaan (MVESIZE), tetapi berhubungan negatif dengan biaya keagenan. Hasil tersebut juga mengindikasikan hazard rate tidak berhubungan dengan aliran kas dan kesempatan tumbuh. Karenanya hasil dari model ekponensial sejalan dengan hasil yang diperoleh dari metode discrete-tiem (logit). Hasil ini mendukung teori pecking order seperti yang dilakukan oleh Deskhmukh (2003) dan Asquith \& Mullin (1983) tapi gagal mendukung teori signaling. Hasil ini juga mendukung teori keagenan tetapi tidak cukup kuat untuk memberikan bukti teori aliran kas dan kesempatan tumbuh.

Tabel 3: Hasil Regresi Persamaan 3

\begin{tabular}{|c|r|r|r|r|}
\hline & \multicolumn{1}{|c|}{ Coefficient } & \multicolumn{1}{c|}{ Std. Error } & z-Statistic & \multicolumn{1}{c|}{ Prob. } \\
\hline C & -0.779118 & 0.196773 & -3.959468 & $0.0001^{*}$ \\
\hline MVESIZE & 0.059037 & 0.023537 & 2.508293 & $0.0121^{*}$ \\
\hline LOGSHOOL & -0.192474 & 0.021493 & -8.955348 & $0.0000^{*}$ \\
\hline CFTOB & -0.002325 & 0.004109 & -0.565899 & 0.5715 \\
\hline GROWTH & 0.226079 & 0.121145 & 1.866189 & 0.0620 \\
\hline Log likelihood & -48.33160 & Number of Observation & 102 \\
\hline
\end{tabular}

\section{Metode Semiparametric Continous-Time}

Metode continous parametric pada bagian sebelumnya mensyaratkan bahwa hazard rate merupakan sepesifikasi suatu fungsi waktu. Cox seperti dikutip oleh Allison (1984) mengusulkan model hazard proposional (proportional hazard rate atau semiparametric continous-time). Metode proporsional ini merupakan salah satu bentuk dari metode continous-time parametric dan memasukan time-varying explanatory variables. Metode ini juga tidak perlu mensyaratkan distribusi waktu hingga dividen inisiasi. Metode semiparamtric continuous-time dirumuskan sebagai berikut:

$\log (\mathrm{ht})=\beta \mathbf{t}+\boldsymbol{\beta}^{\prime} \mathbf{X}_{n}^{t}$

Pada persamaan 4 di atas $\beta$ t bisa merupakan fungsi waktu dan tidak perlu dispesifikasi. Model akurat dalam penelitian ini untuk mengevaluasi pengaruh variable bebas terhadap hazard rate dividen inisiasi. Model ini dikatakan semiparametric karena tidak ada asumsi yang diperlu- 
kan distribusi waktu hingga inisiasi. Model ini diestimasi dengan menggunakan partial likelihood yang merupakan varian dari estimat maximum likelihood. Dengan kata lain prosedur pengestimasian persamaan 4 mengabaikan dasar fungsi hazard rate $(\beta t)$ dan menyediakan estimasi vector $X$.

Dalam hipotesis yang telah diajukan sebelumnya bahwa diperkirakan variabel informasi asimetri mempunyai pengaruh positif terhadap hazard rate (kemungkinan) dividen inisiasi. Hasil pada tabel 4 di atas mendukung hipotesa tersebut. Hazard rate dividen inisiasi secara positif juga berhubungan kesempatan tumbuh, tetapi berasosiasi negatif dengan biaya keagenan. Hasil pada tabel tersebut juga menunjukan aliran kas tidak berhubungan dengan hazard rate. Sekali lagi hasil ini mendukung teori pecking order seperti yang dilakukan oleh Deshkmukh (2003).

Tabel 4: Hasil Regresi Persamaan 3

\begin{tabular}{|c|r|r|r|r|}
\hline & \multicolumn{1}{|c|}{ Coefficient } & \multicolumn{1}{c|}{ Std. Error } & \multicolumn{1}{c|}{ z-Statistic } & \multicolumn{1}{c|}{ Prob. } \\
\hline MVESIZE & 0.057290 & 0.011477 & 4.991644 & $0.0000^{*}$ \\
\hline LOGSHOOL & -0.075256 & 0.026428 & -2.847583 & $0.0044^{*}$ \\
\hline CFTOB & -0.009181 & 0.006346 & -1.446652 & 0.1480 \\
\hline GROWTH & 0.343128 & 0.090411 & 3.795211 & $0.0001^{*}$ \\
\hline Log likelihood & -35.72113 & \multicolumn{4}{|c}{ Number of observation } & 102 \\
\hline
\end{tabular}

* signifikan pada $\square=5 \%$

\section{KESIMPULAN DAN SARAN PENELITIAN LANJUTAN}

Fenomena kebijakan dividen merupakan fenomena yang masih kontroversial dalam literatur keuangan. Penelitian ini menggunakan sample berupa perusahaan-perusahaan yang baru memasuki bursa efek untuk menjelaskan fenomena tersebut di Indonesia. Kelompok perusahaan tersebut diasumsikan dalam tahapan tumbuh (growth stage) sehingga memerlukan banyak dana. Karena masih muda, kelompok perusahaan tersebut kemungkinan besar mengahadapi masalah asimetri informasi. Dua pendekatan yang telah dilakukan pada penelitian-penelitian sebelumnya digunakan untuk menjelaskan fenomena dividen pada kelompok perusahaan yang asimetri informasi: teori signaling dan pecking order. Teori signaling memprediksikan perusahaan memiliki insentif membayar dividen untuk memberikan sinyal kepada pasar mengenai prospek perusahaan sehingga memudahkan menggalang dana masa datang. Akan tetapi teori pecking order berargumen bahwa perusahaan kemungkinan besar justru tidak akan membayar dividen. Kelompok perusahaan yang menjadi sampel memberikan dasar yang kuat untuk menguji teori yang dominan dan menjelaskan kebijakan dividen. 
Dari hasil pengujian sebelumnya, secara keseluruhan dapat disimpulkan bahwa kemungkinan hazard rate berhubungan secara positif dengan ukuran perusuhaan (firm size) dan pertumbuhan perusahaan (MTOB), tetapi berasosiasi negatif dengan biaya keagenan (logshool). Aliran kas (CFTOB) tidak terbukti berhubungan dengan hazard rate dividen inisiasi. Ukuran perusahaan berfungsi sebagai proxy informasi simetri, di mana semakin besar ukuran perusahaan akan semakin kecil informasi simetri. Dengan adanya informasi asimetri, hasil penelitian ini memberikan dukungan pada teori pecking order. Semakin besar ukuran perusahaan maka semakin kecil hazard rate. Dengan kata lain semakin besar ukuran perusahaan, waktu hingga perusahaan tersebut membayar dividen inisiasi tidak lama. Setelah mengontrol variabel asimetri informasi, hazard rate dividen inisiasi tidak memiliki hubungan dengan aliran kas.

Hasil penelitian ini juga konsisten dengan Smith dan Watts (1992 yang menemukan hubungan dividend yield dengan ukuran perusahaan. Tetapi, Smith dan Watt tidak memberikan penjelasan yang kuat alasan hubungan positif yang bersangkutan. Akan tetapi, hasil tersebut juga mendukung teori pecking order. Penelitian ini dilakukan dengan metode pengujian, sampel dan setting yang berbeda, dan tetapi tetap mendukung teori pecking order seperti yang dilakukan oleh Deshkmukh (2003).

Untuk penelitian-penelitian senjutnya, penelitian ini masih bisa dikembangkan dengan misalnya menggunakan proxy asimetri informasi yang berbeda. Logaritma nilai pasar aktiva, logaritma nilai buku aktiva, logaritma jumlah analis dan rasio biaya riset dan pengemangan terhadap nilai buku aktiva juga banyak digunakan sebagai pengukur asimetri informasi. Begitu juga dengan rentang waktu pengamatan, penelitian selanjutnya bisa mengamati periode yang lebih panjang dari 1990-2000.

\section{REFERENSI}

Agus Sartono, 2001. Kepemilikan Orang Dalam (Insider Ownership) Utang dan Kebijakan Dividen: Pengujian Empirik Teori Keagenan (Agency Theory), Jurnal Siasat Bisnis no. 6 Vol. 6 Fakultas Ekonomi Universitas Islam Indonesia 107-119.

Aharony, J. and I. Swany, 1980. Quarterly Dividend and Earnings Announcements and Stockholder Returns: An Empirical Analysis, Journal of Finance 35, 1-12.

Aivazian, V., L. Booth, and S. Cleary, 2001. Dividend Policy in Developing Countries, Paper Presented at the Eighth Annual Conference, Multinational Finance Conference, Italy, 1- 42. 
Allison, P.D., 1984. Event History Analysis-Regression for Longitudinal Event Data (Sage Publications, Newbury Park, CA).

Asquith, P. and D. Mullins, 1983. The Impact of Initiating Dividend Payments on Shareholders' Wealth, Journal of Business 56, 77-96.

Asquith, P. and D. Mullins, Jr., 1983. The impact of initiating dividend payments on shareholders' wealth, Journal of Business 56, 77-96.

Atiase, R.K., 1985. Predisclosure information, firm capitalization, and security price behavior around earnings announcements, Journal of Accounting Research 23, 21-35.

Benartzi, S., R. Michaely, and R. Thaler, 1997. Do Changes in Dividends Signal the Future or the Past? Journal of Finance 52, 1007-1034.

Benartzi, S., R. Michealy, and R. Thaler, 1997. Do changes in dividends signal the future or the past? Journal of Finance 52, 1007-1034.

Bhattacharya, S., 1979. Imperfect information, dividend policy, and the bird in the hand fallacy, Bell Journal of Economics and Management Science 10, 259-270.

Bhattacharya, S., 1979. Imperfect Information, Dividend Policy, and the Bird-in-hand Phallacy, Bell Journal of Economics 10, 259-270.

Bhushan, R., 1989. Firm characteristics and analyst following, Journal of Accounting and Economics 11, 255-274.

Black, F., 1976. The Dividend Puzzle, Journal of Portfolio Management 2, 5-8.

Bursa Efek Jakarta, 1991-2000. Indonesian Capital Market Directory, Bursa Efek Jakarta, Jakarta, 1991, 1992, 1993, 1994, 1995, 1996, 1997, 1998, 1999, 2000.

Collins, D.W., S.P. Kothari, and J.D. Rayburn, 1987. Firm size and the information content of prices with respect to earnings, Journal of Accounting and Economics 9, 111-138.

D'Mello, R. and S.P. Ferris, 2000. The information effects of analyst activity at the announcement of new equity issues, Financial Management, spring, 78-95.

DeAngelo, H., L. DeAngelo, and D. Skinner, 1996. Reversal of Fortune: Dividend Policy and the Disappearance of Sustained Earnings Growth, Journal of Financial Economics 40, 341-371. 
Denis, D.J., D.K. Denis, and A. Sarin, 1994. The information content of dividend changes: Cash flow signaling, overinvestment, and dividend clienteles, Journal of Financial and Quantitative Analysis 29, 567-587.

Deshkmukh, Sanjay, 2003. Dividen Initiation and Asymmetric Information: A Hazard Model, The Financial Review 38, 2003, 351-368.

Dwenter, K. and V. Warther, 1998. Dividends, Asymmetric Information, and Agency Conflicts: Evidence from A Comparison of the Dividend Policies of Japanese and US Firms, Journal of Finance 53, 879-904.

Easterbrook, F., 1984. Two agency-cost explanations of dividends, American Economic Review 74, 650-659.

Greene, William H., 1997. Econometric Analysis, $3^{\text {th }}$ Edition, Prentice-Hall International, Inc.

Healy, P.M. and K.G. Palepu, 1988. Earnings information conveyed by dividend initiations and omissions, Journal of Financial Economics 21, 149-175.

Helwege, J. and N. Liang, 1996. Is there a pecking order? Evidence from a panel of IPO firms, Journal of Financial Economics 40, 429-458.

Higgins, R., 1972. The corporate dividends-savings decision, Journal of Financial and Quantitative Analysis 7, 1527-1541.

Jensen, M., 1986. Agency Cost of Free Cash Flow, Corporate Finance, and Takeovers, American Economic Review Papers and Proceedings 76, 323-329.

Lang, L.H.P., R.M. Stulz, and R.A. Walkling, 1991. A test of the free cash flow hypothesis, Journal of Financial Economics 29, 771-88.

Lasfer, M., 1996. Taxes and Dividends: The UK Evidence, Journal of Banking and Finance 20, 455-472.

Lintner, J., 1956. Distribution of Incomes of Corporations Among Dividends, Retained Earnings and Taxes, American Economic Review 46, $97-133$

Miller, M., and F. Modigliani, 1961. Dividend Policy, Growth, and the Valuation of Shares, Journal of Business 34, 411-433.

Miller, M.H. and K. Rock, 1985. Dividend policy under asymmetric information, Journal of Finance 40, 1031-1051. 
Modigliani, F. and M. Miller, 1958. The Cost of Capital, Corporation Finance, and the Theory of Investment, American Economic Review $53,433-43$.

Myers, S. C. and N. Majluf, 1984. Stock issues and investment policy when firms have information that investors do not have, Journal of Financial Economics 13, 187-221.

Myers, S. C., 1984. The capital structure puzzle, Journal of Finance 39, 575-592.

Opler, T. and S. Titman, 1993. The determinants of leveraged buyout activity: Free cash flow vs. financial distress costs, Journal of Finance 48, 1985-1999.

Rozeff, M., 1982. Growth, beta, and agency costs as determinants of dividend payout ratios, Journal of Financial Research 5, 249-259.

Shores, D., 1990. The association between interim information and security returns surrounding earnings announcements, Journal of Accounting Research 26, 164-181.

Smith, C.W. and R.L.Watts, 1992. The investment opportunity set and corporate financing, dividend, and compensation policies, Journal of Financial Economics 32, 263-292.

Yoon, P. S. and L.T. Starks, 1995. Signaling, investment opportunities, and dividend announcements, Review of Financial Studies 8, 9951018. 